\title{
Major histocompatibility complex and its importance towards controlling infection
}

\author{
Langamba Angom Longjam 1 , Dipmala Das ${ }^{2}$ \\ ${ }^{1}$ Tutor, ${ }^{2}$ Assistant Professor, Department of Microbiology, IQ City Medical College, West Bengal, India
}

It is well documented that infectious pathogen burden and infected cell mass determine the clinical severity of infectious diseases, however, the ability of the host to recognize and process antigens to produce antibodies or the cellular immune response during infection could be under genetic control. The Major Histocompatibility Complex (MHC) or Human Leukocyte Antigen (HLA) system is the most intensively studied of all genetic systems because of its influence to many important traits, including resistance to infectious diseases, autoimmunity and immunological self or nonself compatibility. This is understandable in the light of the evolutionary pressure so that we are equipped to face the multitude of infectious challenges. Infectious diseases are a major selective pressure; and genes involved in the immune response are the most numerous and diverse in the human genome; reflecting the evolutionary advantages of a diverse immunological response to a wide range of infectious pathogens.

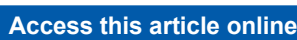

Website:

http://nepjol.info/index.php/AJMS DOI: 10.3126/ajms.v8i2.16189 E-ISSN: 2091-0576 P-ISSN: 2467-9100

Key words: Major histocompatibility complex, Immune response, Autoimmunity, Infectious diseases

\section{INTRODUCTION}

A major part of the global health problem, i.e. $43 \%$, is contributed by the infectious diseases according to the original report of the World Health Organization (WHO). ${ }^{1}$ The susceptibility and resistance to particular microbes leading to infectious disease; is well determined by the complex combination of environmental, pathogen and host genetic factors. This is supported by the various studies that have now mapped and identified relevant genes using a variety of both family based and population based approaches; but only a small fraction of these have been identified so far.

In this era of emerging and re emerging infectious diseases; sometimes it is better to start with the golden pages of the immune system that influences resistance and susceptibility to infectious diseases. As the work continues, the Major Histocompatibility Complex (MHC) or Human Leukocyte Antigen (HLA) system is the most intensively studied of all genetic systems because of its influence to many important traits, including resistance to infectious diseases, autoimmunity, ${ }^{2-7}$ immunological self or nonself compatibility, ${ }^{8}$ spontaneous abortion, ${ }^{9}$ odour and mating preferences. ${ }^{10,11}$ Thus, the MHC plays such a central role in the immune system. These complementary approaches for association in candidate genes is the most common approach using case control studies.

The mouse genetics has contributed to mapping and identification of a few genes. Finally, clues as to what genes affect response to infection in humans are being found in the analysis of outcome of infection in model organisms such as mice or drosophila. ${ }^{12-14}$

More recent, the use of microarray technology has improved in the identification of novel candidate genes on the basis of differential expression, which may eliminate the possibility of false positive associations. This is understandable in the light of the evolutionary pressure so that we are equipped to face the multitude of infectious challenges. Infectious diseases are a major selective pressure; ${ }^{15-18}$ and genes involved in the immune response are the most numerous and diverse in the human genome ${ }^{19}$ reflecting the evolutionary advantages of a diverse immunological response to a wide range of infectious pathogens. ${ }^{20}$ 
Moreover, family based approaches have also become more widely reported to look for linkage to infectious disease in a relatively small number of infectious diseases thus far. ${ }^{21-27}$ Other linkage studies to identify genes causing rare, monogenic susceptibility phenotypes have been reported, though the causative variation identified are rare mutations rather than polymorphisms and the identified genes rarely, if ever, relevant to common variation in susceptibility. ${ }^{28,29}$

Thus, it is an area of intense interest that has been mainly focused on susceptibility to malaria, human immunodeficiency virus (HIV)/acquired immunodeficiency disease syndrome (AIDS) and mycobacterial infection; but other bacterial, viral and parasitic diseases are receiving increasing attention. The emerging picture is of highly polygenic diseases. Moreover, there is a need to review the importance of this system and present in a context so that the other genius explorers become inspire and get the light of knowledge to face the infectious world at present.

\section{Early investigation}

The exploration of MHC genes started through research on tissue rejection using domestic strains of mice and rabbits. In 1916, ${ }^{30}$ Little and Tyzzer performed tumour transplants between different strains of mice, and found that tumours could be transplanted among some strains of mice, but rejected among others. Research on tissue rejection continued and, eleven years later, it was discovered that tissue transplants were not rejected if the donor and the recipient were identical twins. ${ }^{31}$

Studies in mice by Peter Gorer and George Snell ${ }^{132}$ had shown that a histocompatibility system existed, and that it controlled whether tissues could be grafted from one animal to another. It was called the "H-2 system" and there was general agreement that a similar system probably existed in humans. ${ }^{33-38}$

The challenge then was to identify this human histocompatibility system. The detection of the red cells' antigen was well known after discovery of the ABO system. Researchers then turned to white cells as the best avenue for isolating the factors of histocompatibility in humans. Peter Miescher ${ }^{33}$ and others used similar techniques of red cells; mainly agglutination, to begin studies on leukocyte antigens. Jean Dausset ${ }^{34}$ working at a blood bank in France, found antibodies in three patients that reacted similarly. The discovery led him to postulate the first leukocyte antigen group, which he called MAC. Johannes Van Rood; who was also working at a blood bank in Holland, studied leukoagglutinating antibodies in pregnant women, searching for specificities. ${ }^{35}$ From the outset, the problem was the unreliability of the agglutination test because of difficulties in handling granulocytes. To resolve the variability problem, Van Rood came up with the idea of using computers to sort out complex reactions, resulting in the identification of the $4 \mathrm{a}$ and $4 \mathrm{~b}$ specificities. ${ }^{36}$ At about the same time, Rose Payne at Stanford also working on leukoagglutinating antibodies in pregnant women ${ }^{37}$ collaborated with Walter and Julia Bodmer to find two antigenic groups, which they called LA1 and LA2. ${ }^{38}$

In order to agree on methods used for tissue typing, various histocompatibility workshops were performed in which the liabilities of leukoagglutination test, mixed agglutination test, complement fixation test, indirect antiglobulin consumption, mixed lymphocyte culture and the microlymphocyte cytotoxicity test were compared. ${ }^{39-42}$ During these workshops, several leukocyte antigens were identified and made it possible to see for the first time that a single system or genetic locus was producing all these reactions.

After the workshop, a WHO conference was held to decide on nomenclature that was the topic of much confusion and till now also. ${ }^{43}$ Amos summarized the wrangles in the committee,${ }^{44}$ the first antigen of Dausset came to be called HLA2; and Payne and Bodmer's LA1 became HLA1. Thus, the mouse MHC is sometimes known as "H-2", which originated by combining Snell's 'H genes' with Gorer's 'antigen II', and the human MHC is also called 'HLA' or Human Leukocyte Antigen. It is periodically evaluated and revised by the WHO nomenclature committee.

Flemming Kissmeyer-Nielsen provided evidence that there were at least two parts of the HLA system: The A and B loci. ${ }^{45}$ At the fourth workshop, at UCLA in 1970, the microtoxicity test ${ }^{46}$ was adopted as the international standard.

Until the 1970s, the immunological functions of the MHC remained a mystery. The mystery reveals when both Zinkernagel and Doherty found that $\mathrm{T}$ cell responses were restricted, not only to the antigen, but also to MHC molecules in $1975 . .^{47-52}$ Later on, the major applications of HLA for anthropological studies ${ }^{53}$ paternity testing, ${ }^{54}$ etc. were introduced.

\section{HLA genetic architecture}

The human MHC or HLA system is a large chromosomal region of about $3,600 \mathrm{~kb}$ that is located on $6 \mathrm{p} 21.31$ region of short arm of human chromosome 6 (Figure 1) with over 200 allelic variants. ${ }^{55,56}$ Historically, the MHC has been divided into three regions: Class II (centromeric), Class III and Class I (telomeric)..$^{57}$

The human map reveals clusters of genes grouped roughly into a MHC Class I region of 2,000 kb, a MHC 


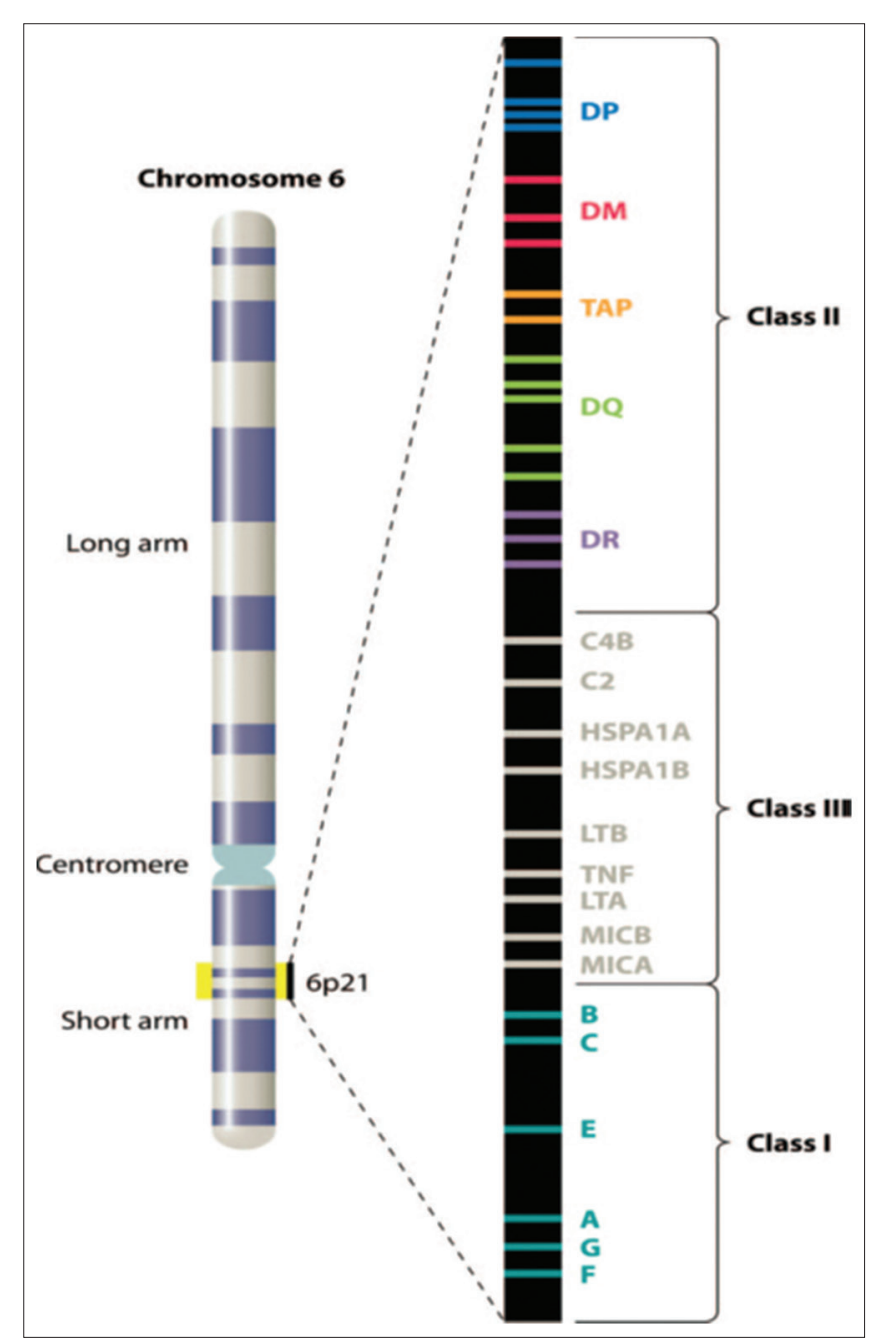

Figure 1: Diagrammatic representation showing the location of the MHC genes on chromosome 6

Class II region of $1,000 \mathrm{~kb}$ and a MHC Class III region of $1,000 \mathrm{~kb}$. The MHC regions Class I and Class II genes control all specific immune responses, but it also contains many other genes that influence growth, development, reproduction, odour and olfaction. Among the MHC loci that control the immune system are Class I and Class II MHC loci (classical MHC genes), which are the most highly polymorphic genes known among vertebrates. It is also highly polygenic implying that it contains several different MHC Class I and MHC Class II genes, so that every individual possesses a set of MHC molecules with different ranges of peptide binding specificities.

MHC Class I $\alpha$ chain gene include HLA-A, HLA-B, HLA-C (classical Ia) and HLA-E, HLA-F, HLA-G (non classical Ib) and are located at telomeric side (Figure 2). MHC Class II $\alpha$ and $\beta$ chains genes (HLA-D); designated with three letter code (e.g., HLA-DRB) indicates Class D, family (M, O, P, Q or $\mathrm{R})$ and chain $(\alpha$ or $\beta$ ), are clustered at centromeric end. Between DMB and DOB genes lie LMP (low molecular

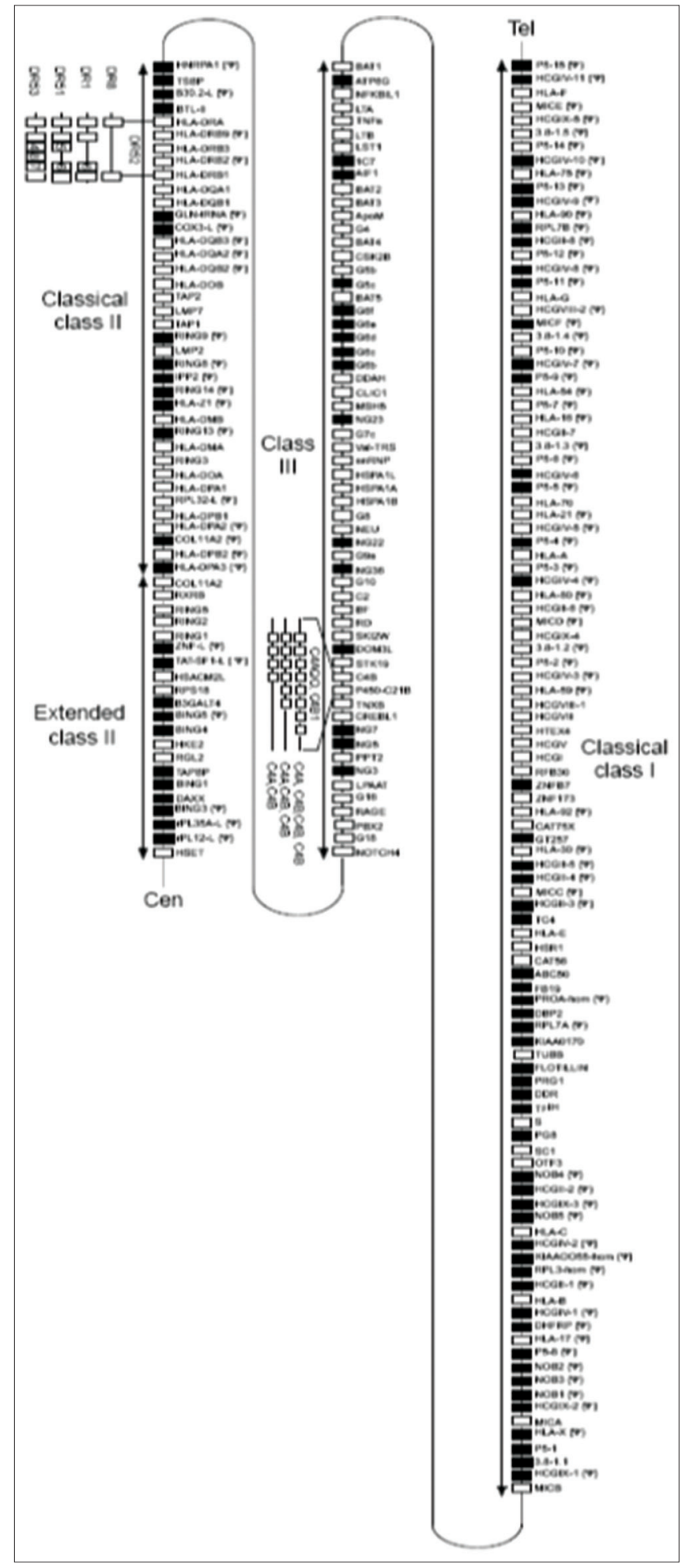

Figure 2: Complete gene map of the MHC reference sequence. A complete picture of all the genes now annotated for the MHC is provided at http://www.nature.com/nrg/journal/v5/n12/poster/MHCmap

weight protein) genes and TAP (transporter associated with antigen processing) genes.

LMP and TAP genes encode molecules that are involved in peptide generation in the cytosol and peptide transport 
across the endoplasmic reticulum (ER) respectively. The classical Class II region is particularly notable because almost all of the genes are of immune function, viz. Class II A and B genes, LMPs, TAPs and TAPBP in the extended Class II region. ${ }^{58}$ Therefore, these LMP and TAP genes are the mainly targeted genes for its association with infectious diseases. LMP2 and LMP7 encode interferon (IFN) $\gamma$ inducible subunits of the immunoproteosome, which degrade ubiquitin tagged cytoplasmic proteins into peptides that are especially suited for presentation by MHC Class I molecules. ${ }^{59,60}$ TAP1 and TAP2 encode subunits of an IFN $\gamma$ inducible heterodimer that binds peptides in the cytoplasm and transports them into the ER where they can be loaded into nascent MHC Class I molecules. ${ }^{60}$

The Class III region does not encode HLA molecules, but contains genes for complement components (C2, C4, factor B), 21 hydroxylase, tumour necrosis factors (TNFs) and some others. ${ }^{61}$

A set of more than seven genes involved in inflammation, including three members of the tumour necrosis factor (TNF) superfamily, within the Class III region is sometimes specified as the Class IV region. ${ }^{62}$

\section{Structure of $\mathrm{MHC}$}

The structure of MHC molecules has been revealed by $\mathrm{X}$-ray crystallography. The Class I molecules consist of extracellular glycosylated invariant $\beta_{2}$ microglobulin $\left(\beta_{2} \mathrm{~m}\right)$ heavy chains that are noncovalently bind to the three extracellular domains $\left(\alpha_{1}, \alpha_{2}\right.$ and $\left.\alpha_{3}\right)$, a transmembrane region and an intracytoplasmic domain. The $\alpha_{1}$ and $\alpha_{2}$ domains contain variable amino acid sequences, and these domains determine the antigenic specificities of the HLA Class I molecules. The $\alpha_{3}$ and $\beta_{2}$ m domains together form immunoglobulin constant domain like folds. ${ }^{63}$

The products of the Class II genes DR, DP and DQ are heterodimers of two noncovalently associated glycosylated polypeptide chains; $\alpha$ and $\beta$. An extracellular portion composed of two domains $\left(\alpha_{1}\right.$ and $\alpha_{2}$, or $\beta_{1}$ and $\left.\beta_{2}\right)$ is anchored on the membrane by a short transmembrane region and an intracytoplasmic domain. Polymorphisms of Class II molecules occur in the first amino terminal $\beta_{1}$ domain of DRB1, DPB1 and DQB1 gene products. ${ }^{64,65}$

As the further studies go on; the MHC genes follow Mendel segregation (Figure 3) during transmission and allelic variant is expressed in a codominant mode. The set of MHC alleles present in each chromosome of the pair is denominated haplotype. The probability of a sibling having the same MHC haplotype as the other is $25 \%$, different haplotypes is $25 \%$ and $50 \%$ are shared for only one haplotype. ${ }^{66}$

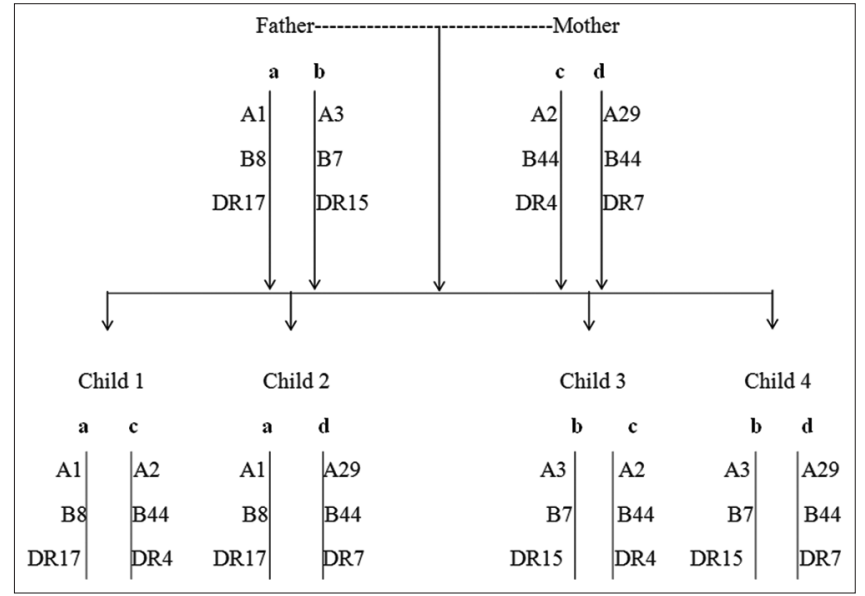

Figure 3: Mendelian inheritance of MHC haplotypes demonstrated in a family study. MHC haplotypes and genotypes can be inferred from phenotype data in an informative family study as illustrated. E.g. The father's phenotype is HLA-A1, 3; B7, 8 and DR15, 17. From the family study, his genotype is A1, B8, DR17 (a) and A3, B7, DR15 (b) and the maternal HLA haplotypes are A2, B44, DR4 (c) and A29, B44, DR7 (d)

Moreover, there is a fact that occurs in HLA genes called linkage disequilibrium which denotes that certain alleles occur together with a greater frequency than would be expected by chance (non random gametic association). Variations in the expected combinations of alleles in the population, more often or less often than would be expected from a random formation of haplotypes from alleles, could be related to linkage disequilibrium.

\section{MHC diversity ${ }^{67}$}

Many evidences indicate that MHC polymorphisms are maintained by natural selection according to Apanius V, Penn D, Slev PR, Ruff LR and Potts WK works as follows:

1. High number of alleles.

2. Uniform allelic frequencies.

3. Deficiencies of homozygotes.

4. Linkage disequilibrium among loci.

5. High nonsynonymous substitution rates at the antigen binding site codons.

6. Ancient allelic lineages (transpecies evolution).

7. Disassortative mating preferences (sexual selection).

HLA and human immunodeficiency virus (HIV) infection/acquired immunodeficiency syndrome (AIDS) The HIVs (HIV 1 and HIV 2) are the greatest challenge to public health in modern times. They are relatively the recent human pathogens that continue to evolve rapidly. The HLA and HIV data are among the most convincing and intriguing in human infection and probably offer the most immediate prospect of harnessing genetic association studies to develop novel interventions. In addition to a number of associations between HLA and clinical phenotypes; and their response to treatment, these data also demonstrate the profound effects of HLA restriction 
on HIV variants that elude immunological control. There are studies on HIV/HLA that provide mechanistic insights into the interaction of HLA molecules and the natural killer (NK) cell receptors.

The virologic and immunologic outcomes in patients with HIV infection can be highly variable; with only a small number of individuals capable of controlling HIV replication without therapy ${ }^{67}$ The control of HIV infection relies on HLA restricted cytotoxic T cell lymphocytes (CTLs) responses, which exert a strong inhibitory effect on viral replication and growth. ${ }^{68}$ Selection for amino acid sequence variants at HIV epitopes may lead to immunological escape by a variety of mechanisms: Interfering with epitope HLA binding, reducing $\mathrm{T}$ cell receptor recognition or generating antagonistic CTL responses. ${ }^{69}$

Earlier studies revealed a relationship between HLA-B*27 and HLA-B*57 and the slow progression to AIDS. ${ }^{70}$ The HLA-B $* 27$ recognises a conserved epitope from the p24 HIV capsid protein and is associated with significantly improved survival in HIV infected individuals. These individuals may maintain high CD4 counts and low level viraemia without antiretroviral therapy. ${ }^{71}$ Conversely, certain other HLA Class I types are associated with rapid diseases progression in HIV. HLA-B*35 restricted escape mutants may affect the recognition of CTL by reducing both peptide binding and $\mathrm{T}$ cell receptor recognition; and HLA-B*35 subtypes are associated with rapid HIV disease progression..$^{72-74}$

A large multi-ethnic cohort with HIV 1 controllers and progressors found diverse alleles associated with virological and immunological control: HLA- $B * 57: 01$, $B * 27: 05, B * 14 / C * 08: 02, B * 52$ and $A * 25 .{ }^{74}$ Furthermore, HLA-B*13:02 $2^{75,76}$ and $B * 58: 01,{ }^{77-79}$ have also been described as favourable prognostic factors. The HLA-B*44 and HLA-B $* 57$ have been described as favourable factors in both the acute and chronic phases of Sub Saharan Africans seroconverters regarding the association of HLA Class I alleles and protection against HIV infection. ${ }^{80}$

\section{HLA and viral hepatitis B and C infections}

About $70 \%$ of the global liver disease is accounted by Hepatitis $\mathrm{B}$ and $\mathrm{C}$ virus infections that are a major public health concern. ${ }^{81}$ The Hepatitis B or C virus infection results either an acute self limited disease or persistent infection. Persistent carriage rates, which confer an increased risk of liver complications, failure or end stage carcinoma, are 10-20\% in Hepatitis B when compared with $\sim 80-90 \%$ of Hepatitis C infections. ${ }^{82}$

A number of candidate gene association studies have identified HLA specific associations for both Hepatitis
B and C susceptibility and outcome. An HLA Class II heterozygote advantage has been demonstrated for clearance of Hepatitis B virus infection ${ }^{83}$ and for progression to end stage liver disease in Hepatitis C. ${ }^{84}$

The HLA associations with Hepatitis B and C virus infection are largely inconsistent across different ethnic groups, and few HLA associations are shared between the two infections, which may reflect both methodological issues and different disease mechanisms. ${ }^{81}$ A meta analysis demonstrated that HLA-DR*03 and HLA-DR*07 were associated with an increased risk of persistent HBV infection in 19 individual case control studies including 9 Han Chinese cohorts, 3 Korean cohorts, 2 Iranian cohorts and 1 cohort each of Caucasian, Gambian, Taiwanese, Thai and Turkish subjects. ${ }^{85}$ HLA-DRB $1 * 07$ is associated with viral persistence in both Hepatitis $B$ and $C$ virus infection in various European and Asian populations ${ }^{86-88}$ and also with Hepatitis B vaccine failure in multiple populations. ${ }^{81,89-91}$

HLA-DRB1*1301 (encoding HLA-DR13) appears to be consistently associated with Hepatitis B virus clearance across a number of diverse populations. ${ }^{92-95} \mathrm{~A}$ genome wide association study (GWAS) identified a significant association of chronic Hepatitis B in Asians with 11 SNPs in a region including HLA-DPA1 and HLA-DPB1; and subsequent analyses revealed risk haplotypes (HLA-DPA*02:02 DPB1*05:01 and HLA-DPA1*02:02 - DPB1*03:01) and protective haplotypes (HLA-DPA1*01:03 - DPB $1 * 04: 02$ and HLA-DPA1*01:03 - DPB1*04:01) for Hepatitis B virus infection. ${ }^{96}$

\section{HLA and Mycobacterium tuberculosis infection}

Tuberculosis (TB) is second only to HIV/AIDS as the greatest killer worldwide due to a single infectious agent. According to the WHO, ${ }^{97}$ in 2014, 9.6 million people fell ill with TB and 1.5 million died from the disease. Over 95\% of TB deaths occur in low and middle income countries. It is a leading killer of HIV positive people causing one fourth of all HIV related deaths. Globally in 2014, an estimated 480,000 people developed multidrug resistant TB (MDR-TB). TB occurs in every part of the world. In 2014, about $80 \%$ of reported TB cases occurred in 22 countries. The frequency and the association of HLA alleles vary among different populations. Thus, the immunological mechanism involved in the breakdown of host resistance in these individual remains unclear.

Cell mediated immunity (CMI) is thought to be the major component of host defense against Mycobacterium species; consequently, the induction of optimal Th1 $\mathrm{CD}^{+}$cells response producing IFN $\gamma$ is protective immunity against Mycobacterial infection especially in the early stages of infection. Functional studies using knockout mice, ${ }^{98,99}$ as 
well as studies of human families with rare genetic lesions at genes encoding IFN $\gamma$ or its receptor, ${ }^{100-102}$ demonstrate the crucial role of this cytokine in defense against tuberculosis and atypical mycobacteria. CD $8^{+} \mathrm{T}$ cells, $\gamma \delta \mathrm{T}$ cells, NK cells and $\mathrm{CD} 1$ restricted $\mathrm{T}$ cells have all been shown to be important IFN $\gamma$ producers in protection against $M$. tuberculosis. ${ }^{103}$ In mice, deficiency in MHC Class II impairs the response to acute infection, while deficiency in MHC Class I has less influence in the acute phase of infection but is crucial during chronic infection. ${ }^{104-106}$

A strong role for MHC Class II molecules is again borne out by the larger number of studies demonstrating association with polymorphisms at HLA-DR and DQ compared to classical Class I molecules. Earlier studies revealed that HLA-DR2/DR3, DR2/DR4 and DR2/ DR5 are the major heterozygous combinations associated with susceptibility to TB. ${ }^{107}$ The HLA Class II variant, DR2 encoded by DRB1*15 and DRB1*16, is associated with TB in several populations. ${ }^{108,109} \mathrm{~A}$ meta analysis study reported that subjects carrying HLA-B13 had a lower risk for thoracic TB, whereas other Class I antigens could not be related to tuberculosis pathogenesis. ${ }^{110}$ Furthermore, HLA-DRB $*^{*} 4$ and HLA-DQB1 $* 02: 01$ were associated with TB in Chinese patients. ${ }^{11}$

Thus, several studies of HLA association with pulmonary tuberculosis have been carried out in Chinese, ${ }^{111,112}$ Korean, ${ }^{113}$ Indonesian, ${ }^{114}$ Indian ${ }^{115-121}$ and Russian patients. ${ }^{122}$ Of the numerous Indian studies on HLA association with pulmonary tuberculosis, the earlier studies focussed on association of HLA Class I antigens ${ }^{115,116}$ and later in family studies in North India ${ }^{118,120}$ and South India ${ }^{117,121}$ that focussed on HLA Class II antigens. An increased frequency of HLA-DR2 and DQ1 was shown to be associated with the susceptibility to pulmonary tuberculosis in Indian population. Molecular study has revealed that the allele DRB1*1501 of HLA-DR2 was higher compared with DRB1*1502 in North Indian patients. ${ }^{117-121,123}$ Moreover, the TAP2 has been found associated with active tuberculosis along with HLA-DR2 in North Indian pulmonary tuberculosis patients. ${ }^{112}$

\section{HLA and Mycobacterium leprae infection}

Prevalence of leprosy globally decreased from $>5$ million cases in the mid 1980s to $<200,000$ by 2015 following introduction of multidrug therapy (MDT) and improved case detection. The prevalence rate was recorded at 0.31 per 10,000 populations, marginally less than that of $2014(0.32$ per 10,000 populations). Globally, however, there are still 3.78 per 100,000 population new case detection rate, mainly in Africa, Americas and Asia. ${ }^{24}$ The causative agent of leprosy, Mycobacterium leprae, is not often a direct killer like most of the cases of tuberculosis. The common severe consequences of leprosy are deformity and disability. The proportion of new Grade 2 disabilities cases globally is $6.6 \%$; as reported by WHO. ${ }^{124}$

Host factors that influence control of the initial infection and the host's immune response plays a significant role in the outcome of infection with either $M$. leprae. In leprosy, the significance of the host response to infection is manifested by the broad clinical spectrum with paucibacillary tuberculoid leprosy (T'T) at one pole and multibacillary lepromatous leprosy (LL) at the other extreme. ${ }^{125}$ The development of the clinical spectrum of the disease is related to the degree of cell mediated immunity (CMI) and is influenced by genetic factors. ${ }^{126-128}$

The TT is characterized by strong CMI, a Th1 CD4+ cytokine profile i.e.,Interleukin (IL) 2, IFN $\gamma$, very few bacteria and localised lesions. The LL is characterized by a lack of CMI Th2 CD4+ responses (IL4 and IL5), a strong humoral response, disseminated progressive disease and large numbers of bacteria. The HLA association have been studied extensively by several investigators so far. ${ }^{126-133}$ Family studies have revealed the presence of three loci that are linked to leprosy. Studies on a South Indian population have revealed that two loci are involved in susceptibility of T'T on the short arms of both chromosomes 10 and 20. ${ }^{134,135}$ Analysis of a cohort of Vietnamese families confirmed the linkage of chromosome 10 and reported a further locus on chromosome $6 .{ }^{136}$ Several studies comparing HLA Class I gene frequencies in leprosy cases and controls have found associations either with the polar forms of leprosy, or with leprosy itself, however these suggested associations have not been replicated as they are limited and inconsistent. ${ }^{130,137-142}$

The association between DR and DQ alleles and different clinical subtypes of leprosy are documented. Several studies reported an association of the HLA-DR2 alleles; HLA - DRB1 $* 15, * 16, * 10$ and $* 12$ with susceptibility or resistance to leprosy in Brazilian, Vietnamese, South Indian, Indonesian, Thai and Argentine populations. ${ }^{143-147}$ DRB1*1501 has been associated with LL ${ }^{148,149}$ whereas DRB1*1502 has been associated with TT. ${ }^{150}$ DQ alleles, especially DQw1 have been shown to be associated with TT in India, ${ }^{148,123}$ Korea, ${ }^{141}$ Thailand,${ }^{149}$ and Japan. ${ }^{151}$ Importantly, HLA DQ1 is in strong linkage disequilibrium with HLA-DR2 in most populations and it has usually been difficult to discern whether the primary association is with the DR or the DQ variant.

\section{HLA and dengue virus infection}

The infection by the Dengue virus has emerged as one of the most important arthropod borne diseases. Human infections can be asymptomatic or can manifest as the 
self limited classical febrile Dengue Fever (DF), or the more severe and life threatening Dengue Haemorrhagic Fever (DHF) and Dengue Shock Syndrome (DSS). It is a mosquito borne viral disease that has rapidly spread in all regions of WHO in recent years. ${ }^{152}$ The subsequent infections by each of the four distinct serotypes (DEN-1, DEN-2, DEN-3 and DEN-4) increase the risk of developing severe dengue. One recent estimate indicates 390 million dengue infections per year, of which 96 million (67-136 million) manifest clinically (with any severity of disease). ${ }^{153}$ Moreover, the other study estimates the risk of dengue infections about 3.9 billion people in 128 countries. ${ }^{154}$

In 2010, 2013 and 2015; nearly 2.4 million cases were reported annually by the Member States in 3 WHO regions. An estimated 500,000 people with severe dengue require hospitalization each year with a large proportion of children. About $2.5 \%$ of those affected die. ${ }^{152}$ Several studies ${ }^{155-163}$ have been conducted about the role of HLA alleles or non HLA alleles in determining resistance, susceptibility or the severity of dengue viral infection, yet only superficial efforts have been made. Thus, a need for detailed genetic studies in different ethnic groups in different countries on a large number of patients is required.

\section{HLA and malaria}

Malaria infection caused by Plasmodium species, is one of the worst scourges of both mankind and wildlife representing a research agenda with global concerns for human health and conservation. ${ }^{164,165} \mathrm{MHC}$ mediated resistance to malaria can be achieved via two major functional pathways. The antigen presentation of MHC Class I proteins, by triggering cytotoxic $\mathrm{T}$ cells against intracellular parasites, may play an important role during the liver stage infection, while Class II molecules can mediate the clearance of parasitized erythrocytes from the bloodstream through the stimulation of helper T cells. ${ }^{166}$

The first convincing association study was carried out in West Africans where the frequent HLA-Bw53 allele and the special DRB1*1302-DQB1*0501 haplotype were associated with reduced susceptibility to severe malaria. ${ }^{166}$ By the turn of the $21^{\text {st }}$ century, some HLA-DR alleles had been associated with an increased antibody response to $\mathrm{Nt} 47$ (p126 aminoterminal portion), ${ }^{167}$ to apical membrane antigen-1 (AMA-1) ${ }^{168}$ of Plasmodium falciparum and to the VK247 CSP repetition of Plasmodium vivax. ${ }^{169}$ The mechanistic link between malaria and the MHC seems evident from some population studies of humans and birds, in which each studied individual variation in the prevalence of certain alleles was associated with tolerance or susceptibility of infection. ${ }^{166,170-175}$ The majority of studies investigating the influence of HLA alleles on the immune response to malaria have been conducted with P. falciparum antigens because of the higher mortality attributed to malaria caused by this parasite. However, these findings were not broadly generalized, and the relationships remained applicable to the specific locality where the data came from as ethnic and/or geographic variations play a major role in this correlation. For example, in a Gambian population, DRB1*13:02 and B*53:01 were associated with reduced susceptibility to severe malaria, ${ }^{166}$ while similar resistance roles were not transparent within the Dogon ethnic group in Mali. ${ }^{171}$

\section{HLA and leishmaniasis}

Leishmaniasis, a neglected tropical disease, prevalent in developing countries with $90 \%$ of them in Asia (Bangladesh, India and Nepal), Sudan, Ethiopia and Brazil. ${ }^{176}$ Due to advances in science and technology, there is evidence to support the fact that the genetic background of the host and the immune response play an important role in the outcome of the leishmaniasis disease. ${ }^{176-186}$

One of the first studies assessing the potential association between HLA and cutaneous leishmaniasis involving serological methods was under taken in France, with Leishmania guyanensis. ${ }^{180}$ The study revealed the association of a low HLA-Cw7 frequency with pathogenesis of cutaneous leishmaniasis.

A serological study in Brazil involving L. braziliensis found that allele HLA-DQw3 was associated with risk of infection and HLA-DR2 was associated with protection against mucocutaneous leishmaniasis. ${ }^{183}$

However, there is no association of HLA-DR2 in any group study of Southern Brazilian population by Ribas-Silva et al ${ }^{186}$ This study also showed a trend towards susceptibility to cutaneous leishmaniasis for alleles HLA-DRB1*13, HLA-B*35 and HLA-B*44. The alleles HLA-B*27, HLA-B*49 and HLA-B*52 tended towards susceptibility, recurrent and reinfection to mucocutaneous leishmaniasis respectively.

The HLA-B $* 45$ alleles tended to provide protection against cutaneous form of American cutaneous leishmaniasis. ${ }^{183}$ The study of Singh $\mathrm{T}$ et a $\mathbf{l}^{176}$ revealed DRB1*13/14 and DRB1*15/16 as risk and protective alleles respectively in visceral leishmaniasis.

\section{CONCLUSION}

There is increasing evidence that HLAs are subject to ongoing selection pressures by infectious pathogens, supporting the theory that natural selection by infectious pathogens plays the central role in maintaining MHC 
polymorphism. Even though, further genome wide linkage studies in different populations will be required to determine the extent of genetic heterogeneity that exists for susceptibility or resistance to the infections. Furthermore, the studied population is highly miscegenated and therefore, results from studies undertaken in a single region should not be generalized to the whole world. The MHC alleles could be in linkage disequilibrium with other relevant genes involved in susceptibility or resistance to pathogens. Such knowledge shall contribute towards future prophylactic and therapeutic interventions and lastly, because of space constraints; only selected work has been cited.

\section{REFERENCES}

1. Global burden of disease [Internet]. Geneva: World Health Organization [updated 2000; cited 2016 April 4]. Available from: http://www.who.int/trade/glossary/story036/en/. English, Arabic, Chinese, French, Portuguese, Spanish, Russian.

2. Djilali-Saiah I, Caillat-Zucman S, Schmitz J, Chaves-Vieira ML and Bach JF. Polymorphism of antigen processing (TAP, LMP) and HLA Class II genes in celiac disease. Human Immunology 1994; 40: 8-16.

3. Moins-Teisserenc $H$, Semana $G$, Alizadeh $M$, Loiseau $P$, Bobrynina V, Deschamps I, et al. TAP2 gene polymorphism contributes to genetic susceptibility to multiple sclerosis. Human Immunology 1995; 42: 195-202.

4. Deng GY, Muir A, Maclaren NK and She JX. Association of LMP2 and LMP7 genes within the Major Histocompatibility Complex with insulin dependent Diabetes mellitus: Population family studies. American Journal of Human Genetics 1995; 56: 528-534.

5. Kumagai S, Kanagawa S, Morinobu A, Takada M, Nakamura K, Sugai $S$, et al. Association of a new allele of the TAP2 gene, TAP2*Bky2 (Val $\left.{ }^{577}\right)$ with susceptibility to Sjogren's syndrome. Arthritis \& Rheumatology 1997; 40: 1685-1692.

6. Fraile A, Nieto A, Beraun Y, Martin J and Mataran L. Association of large molecular weight proteasome 7 gene polymorphism with ankylosing spondylitis. Arthritis \& Rheumatology 1998; 41: $560-562$.

7. Prahalad S, Kingsbury DJ, Griffin TA, Cooper BL, Glass DN, Maksymowych WP, et al. Polymorphism in the MHC encoded LMP7 gene: Association with JRA without functional significance of immunoproteasome assembly. The Journal of Rheumatology 2001; 28: 2320-2325.

8. Kelley $\mathrm{J}$ and Trowsdale J. Features of MHC and NK gene cluster. Transplant Immunology. Science Direct 2005; 14(3-4): 129-134.

9. Reznikoff-Etievant MF, Bonneau JC, Alcalay D, Cavelier B, Toure C, Lobet R, et al. HLA antigen sharing in couples with repeated spontaneous abortions and the birth weight of babies in successful pregnancies. American Journal of Reproductive Immunology 1994; 25(1): 25-27.

10. Garver-Apgar CE, Gangestad SW, Thornhill R, Miller RD and Olp JJ. Major Histocompatibility Complex alleles, Sexual responsivity and unfaithfulness in romantic couples. American Psychological Society 2006; 17(10): 830-835.

11. Ober C, Weitkamp LR, Cox N, Dytch H, Kostyu D and Elias S. HLA and mate choice in humans. American Journal of Human Genetics 1997; 61(3): 497-504.

12. Reiling N, Holscher C, Fehrenbach A, Kroger S, Kirschning CJ, Goyert S, et al. Cutting edge: Toll like receptor (TLR) 2 and
TLR 4 mediated pathogen recognition in resistance to airborne infection with Mycobacterium tuberculosis. The Journal of Immunology 2002; 169: 3480-3484.

13. Lazzaro BP, Sceurman BK and Clark AG. Genetic basis of natural variation in D. melanogaster antibacterial immunity. Science 2004; 303: 1873-1876.

14. Wasserman SA. Nature's fortress against infection. Nature Immunology 2004; 5: 474-475.

15. Frodsham AJ, Hill AV. Genetics of infectious diseases. Human Molecular Genetics 2004; 13(2): R187-194.

16. Sabeti PC, Platko JV, Patterson NJ, McDonald GJ, Ackerman HC, Campbell SJ, et al. Detecting recent positive selection in the human genome from haplotype structure. Nature 2002; 419: 832-837.

17. Tishkoff SA, Dietzsch E, Speed W, Pakstis AJ, Kidd JR, Cheung $\mathrm{K}$, et al. Global patterns of linkage disequilibrium at the CD4 locus and modern human origins. Science 1996; 271: $1380-1387$

18. Walsh EC, Sabeti P, Hutcheson HB, Fry B, Schaffner SF, DeBakker PI, et al. Searching for signals of evolutionary selection in 168 genes related to immune function. Human Genetics 2006; 119: 92-102.

19. McDermott DH, Zimmerman HPA, Guignard F, Kleeberger CA, Leitman SF, Murphy PM, et al. CCR5 promoter polymorphism and HIV1 disease progression. Lancet 1998; 352: 866-870.

20. Apanius V, Penn D, Slev PR, Ruff LR and Potts WK. The nature of selection on the Major Histocompatiblity Complex. Critical Reviews (TM) in Immunology 1997; 17: 179-224.

21. Jepson A, SisayJoof F, Banya W, Hassan King M, Frodsham A, Bennett $S$, et al. Genetic linkage of mild malaria to the Major Histocompatibility Complex in Gambian children: Study of affected sibling pairs. British Medical Journal 1997; 315: 96-97.

22. Marquet $S$, Abel L, Hillaire $D$ and Dessein A. Full results of the genome wide scan which localises a locus controlling the intensity of infection by Schistosoma mansoni on chromosome Sq31-q33. European Journal of Human Genetics 1999; 7: 88-97.

23. Bellamy R, Beyers N, McAdam KP, Ruwende C, Gie R, Samaal P, et al. Genetic susceptibility to tuberculosis in Africans: A genome wide scan. Proceedings of the National Academy of Sciences 2000; 97: 8005-8009.

24. Siddiqui MR, Meisner S, Tosh K, Balakrishnan K, Ghei S, Fisher SE, et al. A major susceptibility locus for leprosy in India maps to chromosome 10p13. Nature Genetics 2001; 27: 439-441.

25. Tosh K, Meisner S, Siddiqui MR, Balakrishnan K, Ghei S, Golding M, et al. A region of chromosome 20 is linked to leprosy susceptibility in a South Indian population. The Journal of Infectious Diseases 2002; 186: 1190-1193.

26. Mira MT, Alcais A, Van Thue N, Thai VH, Huong NT, Ba NN, et al. Chromosome 6q25 is linked to susceptibility to leprosy in a Vietnamese population. Nature Genetics 2003; 33: 412-415.

27. Bucheton B, Abel L, EISafi S, Kheir MM, Pavek S, Lemainque A, et al. A major susceptibility locus on chromosome $22 q 12$ plays a critical role in the control of kala azar. The American Journal of Human Genetics 2003; 73: 1052-1060.

28. Levin M, Newport MJ, D'Souza S, Kalabalikis P, Brown LN, Lenicker HM, et al. Familial disseminated atypical mycobacterial infection in childhood: A human mycobacterial susceptibility gene? Lancet 1995; 345: 79-83.

29. Newport MJ, Huxley CM, Huston S, Hawrylowicz CM, Oostra BA, Williamson $\mathrm{R}$, et al. A mutation in the interferon gamma receptor gene and susceptibility to mycobacterial infection. The New England Journal of Medicine 1996; 335: 1941-1949.

30. Little CC, Tyzzer EE. Further experimental studies on the 
inheritance of susceptibility to a transplantable tumour, carcinoma (J.W.A) of the Japanese waltzing mouse. The Journal of Medical Research 1916; 33(3): 393-453.

31. Bover $\mathrm{KH}$. Homoisotransplantation van Epidermis bei eineigen Zwilligen. Beiträge zur klinischen Chirurgie [Contributions to the Clinical Surgery] 1927; 141: 393-453. German.

32. Gorer PA, Lymen S and Snell GD. Studies on the genetic and antigenetic basis of tumour transplantation. Linkage between a histocompatibility gene and "fused" in mice. Proceedings of the Royal Society B: Biological Sciences 1948; 135: 449.

33. Meischer $\mathrm{P}$ and Fauconnet $\mathrm{M}$. Mise en evidence de different groups leucocytaires chez l'homme [Getting evidence from different groups in human leukocyte]. Schweizerische medizinische Wochenschrift [Swiss Medical Weekly Periodical] 1954; 84: 597. German.

34. Dausset J. Iso-leuco-anticorps [Iso-leuco antibody]. Actahaematologica1958; 20: 156. French.

35. Van Rood JJ, Eernisse JG and Van Leeuwen A. Leukocyte antibodies in sera from pregnant women. Nature 1958; 181: 1735.

36. Payne R and Rolfs MR. Fetomaternal leukocyte incompatibility. Journal of Clinical Investigation 1958; 37: 1756.

37. Van Rood JJ and Van Leeuwen A. Leukocyte grouping. A method and its application. Journal of Clinical Investigation 1963; 42: 1382.

38. Payne R, Tripp M and Weigle J. A new leukocyte isoantigen system in man. Cold Spring Harbor Symposium on Quantitative Biology 1964; 29: 285.

39. Engelfriet $C P$ and Britten $A$. The cytotoxic test for leukocyte antibodies. A simple and reliable technique. Vox Sanguinis 1965; 10: 660-674.

40. Terasaki PI and McClelland JD. Microdroplet assay of human serum cytotoxins. Nature 1964; 204: 998.

41. Balner $\mathrm{H}$, Cleton FJ, Eernisse JG, authors and editors. Joint report. Relation between leukocyte groups and histocompatibility. Histocompatibility Testing 1965: Report of a conference and workshop; 1965 August 15-21; University of Leiden, Netherlands. Copenhagen, DK: Munskgaard; 1965. 288 leaves. Sponsored by Boerhaave courses for Postgraduate Medical education, Netherlands.

42. Ceppellini R, Curtoni ES, Mattiuz PL, Miggiano V, Scudellar G, Serra A. Genetics of leukocyte antigens: A family study of segregation and linkage. In: Curtoni ES, Mattiuz PL, Tosi RM, editors. Histocompatibility Testing 1967: Report of a conference and workshop; 1967 June 14-24; Torino and Saint-Vincent, Italy. Baltimore, US: Williams and Wilkins; 1967. 149-187 p. Sponsored by Consiglio nazionale delle ricerche [National Research Council], Italy.

43. Walford RL. First meeting WHO leukocyte nomenclature committee. New York, September 1968. In: Terasaki PI, editor. History of HLA: Ten recollections; Los Angeles, CA: UCLA tissue typing lab; 1990. $121 \mathrm{p}$.

44. Amos DB. The 1991 nomenclature report. Human Immunology 1992; 34: 1.

45. Kissmeyer-Nielsen F, Svejgaard A, Ahrons $S$ and Nielsen LS. Crossing over within the HLA system. Nature 1969; 224: 75.

46. Mittal KK, Mickey MR, Singal DP and Terasaki PI. Serotyping for homotransplantations 18. Refinement of microdroplet lymphocyte cytotoxicity test. Transplantation 1968; 6: 913-927.

47. Zinkernagel RM and Doherty PC. The Journal of Experimental Medicine 1973; 138: 1266-1269.

48. Zinkernagel RM and Doherty PC. Restriction of in vitro $T$ cell-mediated cytotoxicity in lymphocytic choriomeningitis within a syngeneic or semiallogeneic system.Nature 1974; 248: 701-702.
49. Zinkernagel RM and Doherty PC. Cytotoxic thymus-derived lymphocytes in cerebrospinal fluid of mice with lymphocytic choriomeningitis. J Exp Med 1973;138(5):1266-1269.

50. Doherty PC and Zinkernagel RM. Capacity of sensitized thymus-derived lymphocytes to induce fatal lymphocytic choriomeningitis is restricted by the $\mathrm{H}-2$ gene complex. The Journal of Immunology 1975; 114: 30-33.

51. Doherty PC and Zinkernagel RM. A biological role for the major histocompatibility antigens. Lancet 1975; 1406-1409.

52. Zinkernagel RM. Cellular Immune Recognition and the biological role of major transplantation antigens. Bioscience Reports 1997; 17(2): 91-111.

53. Dausset J, Colombani J, authors and editors. Histocompatibility Testing 1972: Report of an International Workshop and conference; 1972 May 23-27; Evian, France. Copenhagen, DK: Munskgaard; 1972. 778 leaves. Jointly published by Baltimore, US: William and Wilkins. Sponsored by Colloque de l'Institut national de la santé et de la recherché médicale [Symposium The National Institute of Health and Medical sought]. French.

54. Terasaki PI. Resolution of HLA testing of 1000 paternity cases not excluded by ABO testing. Journal of Family Law 1977; 16: 543-557.

55. Horton R, Wilming L, Rand V, Lovering RC, Bruford EA, Khodiyar VK, et al. Gene map of the extended human MHC. Nature Review Genetics 2004; 5(12): 889-899.

56. Geraghty D, Inoko H, Beck S, Trowsdale J, Rowen L, Campbell RD, et al. Complete sequence and gene map of a human Major Histocompatibility Complex [Letters] Nature 1999; 401: p. 921-923.

57. Campbell RD and Trowsdale J. Maps of the human MHC. Immunology Today 1993; 14(7): 349-352.

58. Bodmer WF. Evolutionary significance of the HLA system. Nature 1997; 237: 139-145.

59. Tanaki K. Molecular biology of the proteasome. Biochemical and Biophysical Research Communications 1998; 247: 537-541.

60. Pamer E and Creswell P. Mechanisms of MHC Class I restricted antigen processing. Annual Review of Immunology 1998; 16: 323-358.

61. Beck $S$ and Trowsdale J. The Human Major Histocompatibility Complex: Lessons from the DNA sequence. Annual Review of Genomics and Human Genetics 2000; 1: 117-137.

62. Gruen JR and Weisman SM. Evolving views of the Major Histocompatibility Complex Blood 1997; 90: 4252-4256.

63. Bjorman PJ, Saper MA, Samraoui B, Bennett WS, Strominger JL and Wiley DC. Structure of the human Class I histocompatibility antigen, HLA-A2. Nature 1987; 329: 506-512.

64. Brown JH, Jardetzky TS, Gorga JC, Stern LJ, Urban RG, Strominger JL, et al. Three dimensional structure of the human Class II histocompatibility antigen HLA-DR1. Nature 1993; 364: 33-39.

65. Engelhard VH. Structure of peptides associated with Class I and Class II MHC molecules. Annual Review of Immunology 1994; 12: 181-207.

66. Sung Yoon Choo. The HLA system: Genetics, Immunology: Clinical Testing and Clinical implications. Yonsei Medical Journal 2007; 48(1): 11-23.

67. Buchbinder SP, Katz MH, Hessol NA, O'Malley PM and Holmberg SD. Long term HIV-1 infection without immunologic progression. AIDS 1994; 8: 1123-1128.

68. McMichael A and Klenerman P. HIVIAIDS. HLA leaves its footprints on HIV. Science 2002; 296: 1410-1411.

69. Moore CB, John M, James IR, Christiansen FT, Witt CS and Mallal SA. Evidence of HIV-1 adaptation to HLA restricted 
immune responses at a population level. Science 2002; 296: 1439-1443.

70. Kaslow RA, Carrington M, Apple R, Park L, Munoz A, Saah AJ, et al. Influence of combinations of human Major Histocompatibility Complex genes on the course of HIV-1 infection. Nature Medicine 1996; 2(4): 405-411.

71. Bailey JR, Williams TM, Siliciano RF and Blankson JN. Maintenance of viral suppression in HIV-1 infected HLA-B ${ }^{*} 57+$ Elite suppressors despite CTL escape mutations. The Journal of Experimental Medicine 2006; 203: 1357-1369.

72. Tomiyana H, Miwa K, Shiga H, Moore YI, Oka S, Iwamoto A, et al. Evidence of presentation of multiple HIV-1 cytotoxic T lymphocyte epitopes by $\mathrm{HLA}^{*}{ }^{\star} 35: 01$ molecules that are associated with the accelerated progression of AIDS. The Journal of Immunology 1997; 158: 5026-5034.

73. Gao X, Nelson GW, Karacki P, Martin MP, Phair J, Kaslow R, et al. Effect of a single amino acid change in MHC Class I molecules on the rate of progression to AIDS. The New England Journal of Medicine 2001; 344: 1668-1675.

74. Pereyra F, Jia X, McLaren PJ, Telent A, DeBakkar PI, Walker BD, et al. International HIV controllers study. The major genetic determinants of HIV-1 control affect HLA Class I peptide association. Science 2010; 330: 1551-1557.

75. Honeyborne I, Prendergast A, Pereyra F, Leslie A, Crawford H, Payne R, et al. Control of Human Immunodeficiency Virus type $\mathrm{I}$ is associated with $\mathrm{HLA}-\mathrm{B}^{*} 13$ and targeting of multiple gag specific $\mathrm{CD}^{+} \mathrm{T}$ cell epitopes. Journal of Virology 2007; 81: 3667-3672.

76. Fellay J, Ge D, Shianna KV, Colombo S, Ledergerber B, Ciruli ET, et al. Common genetic variation and the control of HIV 1 in humans. PLOS Genetics 2009; 5(12): e1000791.

77. Kiepiela P, Laslie AJ, Honeyborne I, Ramduth D, Thobakgale C, Chetty $S$, et al. Dominant influence of HLA-B in mediating the potential co-evolution of HIV and HLA. Nature 2004; 432: $769-775$

78. Lazaryan A, Lobashevsky E, Mulenga J, Karita E, Allen S, Tang J, et al. Human leukocyte antigen B58 supertype and Human Immunodeficiency Virus type 1 infection in native Africans. Journal of Virology 2006; 80: 6056-6060.

79. Carlson JM, Lisgarten J, Pfiefer N, Tan V, Kadie C, Walker BD, et al. Widespread impact of HLA restriction on immune control and escape pathways of HIV-1. Journal of Virology 2012; 86: 5230-5243.

80. Tang J, Cormier E, Gilmour J, Price MA, Prentice HA, Song W, et al. Human leukocyte antigen variants $B^{*} 44$ and $B^{*} 57$ are consistently favourable during two distinct phases of primary HIV-1 infection in Sub Saharan Africans with several viral subtypes. Journal of Virology 2011; 85: 8894-8902.

81. Singh R, Kaul R, Kaul A and Khan K. A comparative review of HLA associations with Hepatitis $B$ and $C$ viral infections across global populations. World Journal of Gastroenterology 2007; 13: 1770-1787.

82. Frodsham AJ and Hill AVS. Genetics of infectious diseases. Human Molecular Genetics 2004; 13(2): R187-194.

83. Thursz MR, Thomas HC, Greenwood BM and Hill AV. Heterozygote advantage for HLA Class II type in Hepatitis B Virus infection. Nature Genetics 1997; 17: 11-12.

84. Hraber P, Kuiken C and Yusim K. Evidence for Human Leukocyte Antigen heterozygote advantage against Hepatitis $C$ virus infection. Hepatology 2007; 46: 1713-1721.

85. Tamori A and Kawada N. HLA Class II associated with outcomes of Hepatitis B and C infections. World Journal of Gastroenterology 2013; 19: 5395-5401.

86. Chu RH, Ma LX, Wang G and Shao LH. Influence of HLA-DRB1 alleles and HBV genotypes on interferon alpha therapy for chronic Hepatitis B. World Journal of Gastroenterology 2005; 11: 4753-4757.

87. Kim JH, Pyo CW, Koh DK, Hur JK, Kang JH AND Kim TG. Alteration of the influences of HLA Classes I and II alleles on the perinatal Hepatitis B virus infection after immunoprophylaxis in Korean children. Hepatology Research 2006; 35: 118-126.

88. Wawrzynowicz Syczewska M, Underhill JA, Clare MA, Boron Kaczmarska A, McFarlane IG and Donaldson PT. HLA Class II genotypes associated with chronic Hepatitis $C$ virus infection and response to alpha interferon treatment in Poland. Liver 2000; 20: 234-239.

89. McDermott AB, Zuckerman JN, Sabin CA, Marsh SG and Madrigal JA. Contribution of Human Leukocyte Antigens to the antibody response to Hepatitis $B$ vaccination. Tissue Antigens 1997; 50: 8-14.

90. Qian Y, Zhang L, Liang XM, Hou JL and Luo KX. Association of immune response to Hepatitis B vaccine with HLA-DRB*02, 07 and 09 genes in the population of Han nationality in Guangdong Province. Di Yi Jun Yi Da Xue Xue Bao (Chinese) 2002; 22: 67-69.

91. Amirzargar AA, Mohseni N, Shokrgozar MA, Arjang Z, Ahmadi N, Yousefi Behzadi M, et al. HLA-DRB1, DQA1 and DQB1 alleles and haplotypes frequencies in Iranian healthy adult responders and non responders to recombinant Hepatitis B vaccine. Iranian Journal of Immunology 2008; 5: 92-99.

92. Hohler T, Gerken G, Notghi A, Lubjuhn R, Taheri H, Protzer U, et al. HLA-DRB1*1301 and *1302 protect against chronic Hepatitis B. Journal of Hepatology 1997; 26: 503-507.

93. Ahn SH, Han KH, Park JY, Lee CK, Kang SW, Chon CY, et al. Association between Hepatitis $B$ virus infection and HLA-DR type in Korea. Hepatology 2000; 31: 1371-1373.

94. Hwang SH, Sohn YH, Oh HB, Hwang CY, Lee SH, Shin ES, et al. Human Leukocyte Antigen alleles and haplotypes associated with chronicity of Hepatitis B virus infection in Koreans. Archives of Pathology and Laboratory Medicine 2007; 131: 117-121.

95. Kummee $P$, Tangkijvanich $P$, Poovorawan $Y$ and Hirankarn N. Association of HLA-DRB1*13 and TNF alpha gene polymorphisms with clearance of chronic Hepatitis $B$ infection and risk of hepatocellular carcinoma in Thai population. Journal of Viral Hepatitis 2007; 14: 841-848.

96. Nishida N, Sawai H, Matsuura K, Sugiyama M, Ahn SH, Park JY, et al. Genome-wide association study confirming association of HLA-DP with protection against chronic Hepatitis B and viral clearance in Japanese and Korean. PLOS One 2012; 7(6): e39175.

97. Tuberculosis [Internet]. Geneva: World Health Organization [reviewed 2016 March; cited 2016 April 4]. Available from: http:// www.who.int/mediacentre/factsheets/fs104/en/. English, Arabic, Chinese, French, Portuguese, Spanish, Russian.

98. Cooper AM, Dalton DK, Stewart TA, Griffin JP, Russell DG and Orme IM. Disseminated tuberculosis in interferon gamma gene disrupted mice. The Journal of Experimental Medicine 1993; 178: 2243-2247.

99. Flynn JL, Chan J, Triebold KJ, Dalton DK, Steward TA and Bloom BR. An essential role for interferon gamma in resistance to Mycobacterium tuberculosis infection. The Journal of Experimental Medicine 1993; 178: 2249-2254.

100. Altare F, Jouanguy E, Lamhamedi Cherradi S, Fondaneche MC, Fizame C, Ribierre $\mathrm{F}$, et al. A causative relationship between mutant IFNgR1 alleles and impaired cellular response to IFN gamma in a compound heterozygous child. The American Journal of Human Genetics 1998; 62: 723-726.

101. Jouanguy E, Altare F, Lamhamedi S, Revy P, Emile JF, Newport $\mathrm{M}$, et al. Interferon gamma receptor deficiency in an infant with fatal Bacille Calmette Guerin infection. The New 
England Journal of Medicine 1996; 335: 1956-1961.

102. Newport MJ, Huxley CM, Huston S, Hawrylowicz CM, Oostra BA, Williamson $\mathrm{R}$, et al. A mutation in the interferon gamma receptor gene and susceptibility to mycobacterial infection. The New England Journal of Medicine 1996; 26: 1941-1949.

103. Ladel $\mathrm{CH}$, Blum $\mathrm{C}$, Dreher A, Reifenberg $\mathrm{K}$ and Kaufmann SH. Protective role of gamma/delta $T$ cells and alpha/beta $T$ cells in tuberculosis. European Journal of Immunology 1995; 25: 2877-2881.

104. Ladel CH, Daugelat S and Kaufmann SH. Immune response to Mycobacterium bovis Bacille Calmette Guerin infection in Major Histocompatibility Complex Class I and II deficient knockout mice: Contribution of CD4 and CD8 T cells to acquire resistance. European Journal of Immunology 1995; 25: 377-384.

105. Rolph MS, Raupach B, Kobernick HH, Collins HL, Perarnau B, Lemonnier FA, et al. MHC Class la restricted T cells partially account for beta2 microglobulin dependent resistance to Mycobacterium tuberculosis. European Journal of Immunology 2001; 31: 1944-1949.

106. Sousa AO, Mazzaccaro RJ, Russell RG, Lee FK, Turner OC, Hong $S$, et al. Relative contributions to tuberculosis infection in mice. Proceedings of the National Academy of Sciences 2000; 97: 4204-4208.

107. Selvaraj $P$, Reetha AM, Uma $H$, Xavier T, Janardhanam B, Prabhakar R, et al. Influence of HLA-DR and DQ phenotypes on tuberculin reactive status in pulmonary tuberculosis. Tubercle and Lung Disease 1996; 77: 369-373.

108. Dubaniewicz A, Lewko B, Moszkowska G, Zamorska B and Stepinski J. Molecular subtypes of the HLA-DR antigens in pulmonary tuberculosis. International Journal of Infectious Diseases 2000; 4: 129-133.

109. Rojas-Alvarado MDL, Diaz-Mendoza ML, Said-Fernandez S, Caballero-Ohn G and Cerda-Flores RM. Association of pulmonary tuberculosis with HLA system antigens in Northeastern Mexico. Gaceta Medica de Mexico [Medical Gazette of Mexico] 2008; 144: 233-238.

110. Kettaneh L, Seng KP, Tiev C, Toledano B and Fabre JC. Human leukocyte antigens and susceptibility to tuberculosis: A meta analysis of case control studies. Intertional Journal of Tuberculosis and Lung Disease 2006; 10: 717-725.

111. Wu F, Zhang W, Zhang L, Wu J, Li C, Meng X, et al. NRAM P1, VDR, HLA-DRB1 and HLA-DQB1 gene polymorphisms in susceptibility to tuberculosis among the Chinese Kazakh population: A case control study. BioMed Research International 2013; 2013: 1-8.

112. Hawkins BR, lliggins DA, Chan SL, Lourie DB, Mitchison DA and Girling DI. HLA typing in the Hong Kong Chest Service/British Medical Research Council study of factors associated with the breakdown to active tuberculosis of inactive pulmonary lesions. The American Review of Respiratory Disease 1988; 138: 1616.

113. Aizawa M, editor-in-chief; Natori T, Wakisaka A, Konoeda Y, coeditors. HLA in Asia-Oceania 1986: Proceedings of the Third Asia-Oceania Histocompatibility Workshop and Conference. Sappora, Japan: Hokkaido University Press; 1140 leaves.

114. Bothamley GH, Beck JS, Schreuder GM, D'Amaro J, DeVries RR, Kardjito T, et al. Association of tuberculosis and M. tuberculosis specific antibody levels with HLA. The Journal of Infectious Diseases 1989; 159: 549.

115. Papiha SS, Wentzed $\mathrm{J}$ and Behjati $F$. Human leukocyte antigens and circulating immunoglobulin levels in Indian patients with pulmonary tuberculosis. Tubercle 1985; 66: 25.

116. Papiha SS, Singh BN, Lanchbury JS, Roberts DF, Parsad CE, Wentzel J, et al. Association of HLA and other genetic markers in south Indian patients with pulmonary tuberculosis. Tubercle 1987; 68: 159.
117. Brahmajothi V, Pitchappan RM, Kakkanaiah VN, Sashidhar M, Rajaram K, Ramu S, et al. Association of pulmonary tuberculosis and HLA in South India. Tubercle 1991; 72: 123.

118. Singh SPH, Mehra NK, Dingley HB, Pandey IN and Vaidya MC. Human Leukocyte Antigen (HLA) linked control of susceptibility to pulmonary tuberculosis and association with HLA-DR types. The Journal of Infectious Diseases 1983; 148-676.

119. Sanjeevj CB, Narayanan PR, Prabhakar R, Charles N, Thomas BE, Balasubramaniam $\mathrm{R}$, et al. No association or linkage with HLA-DR or DQ genes in South Indians with pulmonary tuberculosis. International Journal of Tuberculosis and Lung Disease 1992; 73: 280.

120. Rajalingam R, Mehra NK, Jain RC, Mynedu VP and Pande IN. Polymerase chain reaction based sequence specific oligonucleotide hybridisation analysis of HLA Class II antigens in pulmonary tuberculosis: Reference to chemotherapy and disease severity. The Journal of Infectious Diseases 1996; 173: 669.

121. Selvaraj $P$, Uma $H$, Reetha AM, Kurian SM, Xavier $T$, Prabhakar R, et al. HLA antigen profile in pulmonary tuberculosis patients and their spouses. Indian Journal of Medical Research 1998; 107: 155.

122. Khomenko AG, Litvinov VI, Chukanova VP and Pospelov LE. Tuberculosis in patients with various HLA phenotypes. Tubercle 1990; 71: 187.

123. Mehra NK, Rajalingam R, Mitra DK, Taneja V and Giphart MJ. Variants of HLA-DR2/DR51 group haplotypes and susceptibility to tuberculoid leprosy and pulmonary tuberculosis in Asian Indians. International Journal of Leprosy 1995; 63(2): 241-248.

124. Weekly Epidemiological Record: Leprosy. Vol. 90. Geneva: World Health Organization; 2015 September. p. 461-476. Report No.: 36. English, Arabic, Chinese, French, Portuguese, Spanish, Russian.

125. Ridley DS and Jopling WH. Classification of leprosy according to immunity: A five group system. Intertional Journal of Leprosy and Other Mycobacterial Diseases 1966; 34: 255-273.

126. DeVries RR, Fat RF, Nijenhuis LE and Van Rood JJ. HLA linked genetic control of host response to Mycobacterium leprae. Lancet 1976; 2(7999): 1328-1330.

127. DeVries RRP, Ottenhoff THM and Van Schooten WCA. Human Leukocyte Antigens (HLA) and Mycobacterial disease. Seminars in Immunopathology 1998; 10: 305-318.

128. Fine PEM. Implications of genetics for the epidemiology and control of leprosy. Philosophical Transactions of the Royal Society B Biological Sciences 1988; 321: 365-376.

129. Fine PEM, Wolf E, Pritchard J, Watson B, Bradley DJ, Festeinstein $\mathrm{H}$, et al. HLA linked genes and leprosy; a family study in Karagiri, South India. The Journal of Infectious Diseases 1979; 140: 152-161.

130. Izumi S, Sugiyama K, Matsumoto Y and Othkawa S. Analysis of the immunogenetic background of Japanese leprosy patients by the HLA system. Vox Sanguinis 1982; 42(5): 243-247.

131. Todd JR, West BC and McDonald JC. Human leukocyte antigen and leprosy: Study in Northern Louisiania and review. Reviews of Infectious Diseases 1990; 12: 63-74.

132. Van Eden W and DeVries RRP. HLA and leprosy: A re-evaluation. Leprosy Review 1984; 55: 89-104.

133. Youngchaiynd $U$, Chandanayingyong $D$ and Vibhatavanija $T$. The incidence of HLA antigens in leprosy. Vox Sanguinis 1997; 32: $342-345$

134. Siddiqui MR, Meisner S, Tosh K, Balakrishnan K, Ghei S, Fisher SE, et al. A major susceptibility locus for leprosy in India maps to chromosome 10p13. Nature Genetics 2001; 27: 439-441. 
135. Tosh K, Meisner S, Siddiqui MR, Balakrishnan K, Ghei S, Golding M, et al. A region of chromosome 20 is linked to leprosy susceptibility in a South Indian population. The Journal of Infectious Diseases 2002; 186: 1190-1193.

136. Mira MT, Alcais A, VanThue N, Thai VH, Huong NT, Ba NN, et al. Chromosome $6 \mathrm{q} 25$ is linked to susceptibility to leprosy in a Vietnamese population. Nature Genetics 2003; 33: 412-415.

137. Serjeantson SW. HLA and susceptibility to leprosy. Immunological Reviews 1983; 70: 89-112.

138. Rani R, Zaheer SA and Mukherjee R. Do human leukocyte antigens have a role to play in differential manifestation of multibacillary leprosy: A study on multibacillary leprosy patients from South India. Tissue Antigens 1992; 40: 124-127.

139. Greiner J, Schleiermacher E, Smith T, Lenhard V and Vogel F. The HLA system and leprosy in Thailand. Human Genetics 1978; 42: 201-213.

140. Takata H, Soda M, Ozawa S and Sekiguchi S. HLA and mycobacterial infection: Increased frequency of B8 in Japanese leprosy. Tissue Antigens 1978; 11: 61-64.

141. Kim SJ, Choi IH, Dahlberg S, Nisperos B, Kim JD and Hansen JA. HLA and leprosy in Koreans. Tissue Antigens 1987; 29: 146-153.

142. Rea TH, Levan NE and Terasaki PI. Histocompatibility antigens in patients with leprosy. The Journal of Infectious Diseases 1976; 134: 615-618.

143. Vanderborght PR, Pacheco AG, Moraes ME, Antoni G, Romero M, Verville A, et al. HLA-DRB1*04 and DRB1*10 are associated with resistance and susceptibility, respectively, in Brazilian and Vietnamese leprosy patients. Genes and Immunity 2007; 8(4): 320-324.

144. Tosh K, Ravikumar M, Bell JT, Meisner S, Hill AV and Pitchappan R. Variation in MICA and MICB genes and enhanced susceptibility to paucibacillary leprosy in South India. Human Molecular Genetics 2006; 15(19): 2880-2887.

145. Schauf V, Ryan S, Scollard D, Jonasson O, Brown A, Nelson K, et al. Leprosy associated with HLA-DR2 and DQw1 in the population of northern Thailand. Tissue Antigens 1985; 26: 243-247.

146. Soebon H, Giphart MJ, Schreuder GM, Klatser PR and DeVries RRP. Associations between HLA-DRB1 alleles and leprosy in an Indonesian population. International Journal of Leprosy and Other Mycobacterial Diseases 1997; 65(2): 190-196.

147. Motta PM, Cech N, Fontan C, Gimenez MF, Lodeiro N, Marinic K, et al. Role of HLA-DR and HLA-DQ alleles in multibacillary leprosy and paucibacillary leprosy in the province of Chaco (Argentina). Enfermedades Infecciosas y Microbiología Clínica [Infectious Diseases and Clinical Microbiology] 2007; 25(10): 627-631. Spanish.

148. Rani R, Fernandez-Vina MA, Zaheer SA, Beena KR and Stastny P. Study of HLA Class II alleles by PCR oligotyping in leprosy patients from North India. Tissue Antigens 1993; 42: 133-137.

149. Schauf V, Ryan S, Scollard D, Jonasson O, Brown A, Nelson K, et al. Leprosy associated with HLA-DR2 and DQw1 in the population of northern Thailand. Tissue Antigens 1985; 26: 243-247.

150. Mehra NK, Verduijn W, Taneja V, Drabbels J, Singh SP and Giphart MJ. Analysis of HLA-DR2 associated polymorphisms by oligonucleotide hybridization in an Asian Indian population. Human Immunology 1991; 32(4): 246-253.

151. Joko S, Numaga J, Masuda K, Namisato M and Maeda H. HLA Class II alleles and leprosy (Hansen's disease) classified by WHO-MDT criteria. Nippon Rai Gakkai Zasshi [Japan Leprosy Journal]1996; 65: 121-127. Japanese.

152. Dengue and severe dengue [Internet]. Geneva: World Health
Organization [updated 2016 March; cited 2016 April 4]. Available from: http://www.who.int/mediacentre/factsheets/fs117/en/. English, Arabic, Chinese, French, Portuguese, Spanish, Russian.

153. Bhatt S, Gething PW, Brady OJ, Messina JP, Farlow AW, Moyes $\mathrm{CL}$, et al. The global distribution and burden of dengue. Nature 2013; 496(7446): 504-507.

154. Brady OJ, Gething PW, Bhatt S, Messina JP, Brownstein JS, Hoen AG, et al. Refining the global spatial limits of dengue virus transmission by evidence based consensus. PLOS Neglected Tropical Diseases 2012; 6(8): e1760.

155. Chiewsilp P, McNair Scott $R$ and Bramarapravati $N$. Histocompatibility Antigens and Dengue Haemorrhagic Fever. The American Journal of Tropical Medicine and Hygiene1981; 30: 1100-1105.

156. Paradoa Perez ML, Trujillo $Y$ and Lasanta P. Association of Dengue Haemorrhagic Fever with the HLA system. Haematologia 1987; 20: 83-87.

157. Sierra B, Alegre R, Perez AB, Garcia G, Sturn-Ramirez K, Obasanjo O, et al. HLA-A, B, C and DRB1 allele frequencies in Cuban individuals with antecedents of dengue 2 disease. Advantages of the Cuban population for HLA studies of Dengue virus infection. Human Immunology 2007; 68: 531-540.

158. LaFleur C, Granades J, Vargas-Alarcon G, Ruiz-Morales J, Villareal-Garza C, Higuera L, et al. HLA-DR antigen frequencies in Mexican patients with Dengue virus infection: HLA-DR4 as a possible genetic resistance factor for Dengue Haemorrhagic Fever. Human Immunology 2002; 63: 1039-1044.

159. Polizel JR, Bueno D, Visentainer JE, Sell AM, Borelli SD, Tsuneto LT, et al. Association of Human Leukocyte Antigen DQ1 and dengue fever in a white Southern Brazilian population. Memórias do Instituto Oswaldo Cruz [Memories of the Oswaldo Cruz Institute] 2004; 99: 559-562. Brazil.

160. Stephens HAF, Klaythong R, Sirikong M, Vaughn DW, Green S, Kalayanarooj S, et al. HLA-A and B allele associations with secondary dengue virus infections correlate with disease severity and the infecting viral serotype in ethnic Thais. Tissue Antigens 2002; 60: 309-318.

161. Lan NTP, Kikuchi M, Huong VTQ, Ha DQ, Thuy TT, Tham VD, et al. Protective and enhancing HLA alleles, HLA-DRB1*0901 and HLA-A*24, for severe forms of Dengue Virus Infection, Dengue Haemorrhagic Fever and Dengue Shock Syndrome. PLOS Neglected Tropical Diseases 2008; 2: 1-8.

162. Loke H, Bethell DP, Phuong CXT, Dung M, Schneider J, White NJ, et al. Strong HLA Class I restricted T cells responses in Dengue haemorrhagic Fever. A double-edged swords? The Journal of Infectious Diseases 2001; 184: 1369-1373.

163. Loke H, Bethell DP, Phuong CXT, Day N, White N, Farrar J, et al. Susceptibility to Dengue Haemorrhagic Fever in Vietnam: Evidence of an Association with variation in the Vitamin D Receptor and FCÁ Receptor II A genes. The American Journal of Tropical Medicine and Hygiene 2002; 67: 102-106.

164. Snow RW, Guerra CA, Noor AM, Myint HY and Hay SI. The global distribution of clinical episodes of Plasmodium falciparum malaria. Nature 2005; 434: 214-217.

165. Sachs $\mathrm{J}$ and Malaney P. The economic and social burden of malaria. Nature 2002; 415: 680-685.

166. Hill AVS, Allsopp CEM, Kwiatkowski D, Anstey NM, Twumasi P, Rowe PA, et al. Common West African HLA antigens are associated with protection from severe malaria. Nature 1991; 352: 595-600.

167. Banic DM, Goldberg AC, Pratt-Riccio LR, Oliveira-Ferreira J, Santos F, Gras-Masse H, et al. Human Leukocyte Antigen Class II control of the immune response to $\mathrm{p} 126$ derived aminoterminal peptide from Plasmodium falciparum. The American Journal of 
Tropical Medicine and Hygiene 2002; 66(5): 509-515.

168. Johnson $A H$, Lee RG, Mendell NR, Shon D, Suh $Y J$, Bomba-Nkolo D, et al. Human Leukocyte Antigen Class II alleles influence levels of antibodies to the Plasmodium falciparum asexual stage apical membrane antigen 1 but not to merozoite surface protein 1 . Infection and Immunity $2004 ; 72(5)$ : 2762-2771.

169. Oliveira-Ferreira J, Pratt-Riccio LR, Arruda M, Santos F, Ribeiro CT, Goldberg AC, et al. HLA Class II and antibody responses to circumsporozoite protein repeats of Plasmodium vivax (VK210, VK247 and $P$. vivax-like) in individuals naturally exposed to malaria. Acta Tropica 2004; 92(1): 63-69.

170. Hill AVS, Elvin J, Willis AC, Aidoo M, Allsopp CEM, Gotch FM, et al. Molecular analysis of the association of HLA-B53 and resistance to severe malaria. Nature 1992: 360: 434-439.

171. Lyke KE, Fernandez-Vina MA, Cao K, Hollenbach J, Coulibaly D, Kone AK, et al. Association of HLA alleles with Plasmodium falciparum severity in Malian children. Tissue Antigens 2011; 77: 562-571.

172. May J, Meyer CG, Kun JFJ, Lell KB, Luckner D, Dippmann AK, et al. HLA Class II factors associated with Plasmodium falciparum merozoite surface antigen allele families. The Journal of Infectious Diseases 1999; 179: 1042-1045.

173. May J, Lell B, Luty AJF, Meyer CG and Kremsner PG. HLADQB1*0501 restricted Th1 type immune responses to Plasmodium falciparum liver stage antigen 1 protect against malaria anaemia and re-infections. The Journal of Infectious Diseases 2001;183: 168-172.

174. Osafo-Addo AD, Koram KA, Oduro AR, Wilson M, Hodgson A and Rogers WO. HLA-DRB1 ${ }^{*} 04$ allele is associated with severe malaria in Northern Ghana. The American Journal of Tropical Medicine and Hygiene 2008; 78: 251-255.

175. Westerdahl $H$, Waldenstrom J, Hansson B, Hasselquist D, Von Schantz T and Bensch S. Associations between malaria and $\mathrm{MHC}$ genes in a migratory bird. Proceedings of the Royal Society B Biological Sciences 2005; 272: 1511-1518.

176. Singh T, Fakiola M, Oommen J, Chakravarty J, Sundar S and Blackwell J. HLA Class II association with visceral leishmaniasis: The road to identifying vaccine candidates. Poster session presented at: $16^{\text {th }}$ ICID [International Congress on Infectious Diseases] 2014 April 2-5; Capetown, South Africa.

177. Bradley DJ. Genetic control of natural resistance to Leishmania donovani. Nature 1974; 250: 353.

178. Peréz H, Labrador F and Torrealba JW. Variation in the response of five strains of mice to Leishmania mexicana. International Journal for Parasitology1979; 9: 27.

179. Blackwell J, Freeman J and Bradley D. Influence of H-2 complex on acquired resistance to Leishmania donovani. Nature 1980; 283: 72.

180. Barbier D, Demenais F, Lefait JF, David B, Blanc M, Hors J, et al. Susceptibility to human cutaneous leishmaniasis and HLA, Gm, Km markers. Tissue Antigens 1987; 30: 63-67.

181. Roberts $\mathrm{M}$, Alexander $\mathrm{J}$ and Blackwell J. Influence of Lsh, H-2 and an $\mathrm{H}-11$ linked gene on visceralization and metastasis associated with Leishmania mexicana infection in mice. Infection and Immunity 1989; 57(3): 875-881.

182. Lara ML, Layrisse Z, Scorza JV, García E, Stoikow Z, Granadaos J, et al. Immunogenetics of human American cutaneous leishmaniasis. Study of HLA haplotypes in 24 families from Venezuela. Human Immunology 1991; 30: 129-135.

183. Petzl-Erler ML, Belich MP and Queiroz-Telles F. Association of mucosal leishmaniasis with HLA. Human Immunology 1991; 32: $254-260$

184. Olivo-Diaz A, Debaz H, Alaez C, Islas VJ, Perez-Perez H, Hobart $\mathrm{O}$, et al. Role of HLA Class II alleles in susceptibility to and protection from localized cutaneous leishmaniasis. Human Immunology 2004; 65: 255-261.

185. Donaghy L, Gros F, Amiot L, Mary C, Maillard A, Guiguen C, et al. Elevated levels of soluble non-classical Major Histocompatibility Class I molecule Human Leukocyte Antigen (HLA)-G in the blood of HIV infected patients with or without visceral leishmaniasis. Clinical and Experimental Immunology 2007; 147(2): 236-240.

186. Ribas-Silva RC, Ribas AD, Dos Santos MCG, DaSilava WV, Lonardoni MVC, Borelli SD, et al. Association between HLA genes and American cutaneous leishmaniasis in endemic regions of Southern Brazil. Biomed Central Infectious Diseases 2013; 13: 198

Authors Contribution:

LLA - Literature search, Review of literature, Manuscript preparation and Critical revision of the manuscript; DD - Concept and Design of the study.

Source of Support: Nil, Conflict of Interest: None of the authors has potential conflict of interest related to this manuscript. 